Max-Planck-Institut für demografische Forschung

Max Planck Institute for Demographic Research

Konrad-Zuse-Strasse $1 \cdot$ D-18057 Rostock · GERMANY

Tel +49 (0) 3812081 - 0; Fax +49 (0) 3812081 - 202;

http://www.demogr.mpg.de

MPIDR WORKING PAPER WP 2008-020

JUNE 2008

\title{
Patterns of Partnership Formation among Lone Mothers in Russia
}

Cordula Zabel (cordula.zabel@iab.de)

This working paper has been approved for release by: Jan M. Hoem (hoem@demogr.mpg.de)

Head of the Laboratory of Contemporary European Fertility and Family Dynamics.

(C) Copyright is held by the authors.

Working papers of the Max Planck Institute for Demographic Research receive only limited review. Views or opinions expressed in working papers are attributable to the authors and do not necessarily reflect those of the Institute. 


\title{
Patterns of Partnership Formation among Lone Mothers in Russia
}

Cordula Zabel

\begin{abstract}
This study examines the determinants of partnership formation among lone mothers in Russia, using data from the Russian Generations and Gender Survey (GGS) and the Education and Employment Survey (EES). The central research question is whether difficult economic circumstances pressure lone mothers to enter new partnerships sooner than they would under other circumstances, limiting their freedom of choice of type of living arrangement. The empirical results show that while occupation influences lone mothers' rates of partnership formation both before and after 1991, a significant effect of employment status does not appear until after 1991. Apart from economic factors, demographic factors such as the age and number of children are also shown to have an important impact on lone mothers' rates of partnership formation. Comparisons to patterns of partnership formation among childless women are also presented.
\end{abstract}

\section{Introduction}

The proportion of families in Russia headed by lone mothers is quite high, due especially to high divorce rates and to a lesser extent to relatively high proportions of non-marital births. In this paper we look into factors affecting lone mothers' freedom of choice of type of living arrangement. Access to employment and childcare as well as the ability to achieve incomes high enough to support their families are factors that are likely to be important for lone mothers' autonomy. Low incomes may put pressure on lone mothers to begin new partnerships sooner than they would under other circumstances. A special focus in this paper is a comparison of the impact of employment characteristics on patterns of partnership formation before and after the transition in the light of a changing labor market and institutional setting. 
While difficult economic circumstances may put pressure on lone mothers to begin new partnerships earlier than they otherwise would, lone mothers are also likely to be faced with important obstacles with respect to partnership formation. Time constraints can make it more difficult for them to meet potential partners. The responsibility of caring for children, especially when they are very young, may also make lone mothers less attractive as partners. Research questions examined refer to the influence of children's age and the number of children on lone mothers' rates of transition into new partnerships.

The first part of this paper provides the background for the research questions. First, an overview is given of the development of rates of divorce and non-marital childbearing, the two main pathways into lone motherhood, as well as of the overall prevalence of lone-mother households in Russia. The literature concerning the economic situation of lone mother households in Russia is reviewed, and an overview of childcare provision and family policy changes in Russia is presented. A final section of the background part of the paper compares the economic situation of lone mother families in Russia with the situation in other countries. The background information provided in the first part of this paper is then drawn together to formulate research questions on lone mothers' patterns of partnership formation in Russia.

The empirical part of the paper begins with a description of the data used and the method of analysis. This is followed by models testing the effects of demographic and economic factors on partnership formation of lone mothers in Russia before and after 1991. Additionally, comparisons to patterns of partnership formation of childless women are presented. The main findings are summarized in a conclusion.

\section{Development of divorce, non-marital childbearing, and lone motherhood in Russia}

The two main pathways into lone motherhood are divorce and non-marital childbearing. Throughout recent decades, divorce rates in Russia have been quite high compared to other European countries. Divorce rates increased abruptly after divorce procedures were simplified in 1965, and continued to rise gradually throughout the 1970s. They then remained quite stable in the 1980s, followed by strong fluctuations between 1990 and 2004 (Jasilioniene 2007; Moskoff 1983). Therefore, it can be assumed that lone-mother 
families, too, became more common in the period between the 1980s and the present than they had been before.

Non-marital birth rates were also quite high in Russia by international comparisons in the 1960s and 1970s. Non-marital birth rates then started rising in many European countries in the late 1970s and 1980s, leaving Russia behind. Non-marital childbearing in Russia increased strongly again in the 1990s (Council of Europe 2005). Following a trend begun in the 1980s though, entries into cohabitation as a first union type increased as well during the same period, while entries into marriage decreased (Hoem, Jasilioniene, Kostova, Muresan 2007). Thus it is likely that many of the non-marital births observed in the 1990s are births within cohabiting unions.

Indeed, most lone-mother households are households led by divorced or separated mothers (still registered as married) rather than by never-married mothers. According to figures reported by Kanji (2004) for the year 2000, more than twice as many children lived in households led by divorced or separated mothers (9.5\%), than in households led by never-married lone mothers (3.6\%). Thus, altogether, including children living with widowed lone mothers (2.3\%), around 15\% of children lived in lone-mother households. Much fewer (4\%) lived in lone-father households. The proportion living in step-family households was lower, at around 7\%.

Estimates shown in Table 1 based on data from the Generations and Gender Survey (GGS) for the year 2004 even indicate somewhat higher proportions of children living in lone mother households. It was not possible to calculate directly the total proportion of children living with lone mothers from the GGS data. Children living only with their mother made up $8 \%$ of all children, but the data did not allow us to distinguish children who were living with only one parent and relatives (on the one hand) from those living with both parents or no parent and relatives (on the other). Seen from the perspective of mothers, the picture becomes a bit clearer. Of all mothers of children aged $0-15$, 9\% lived alone with their children. An additional 11\% lived with their children and relatives, but without a partner. Thus, a total of $20 \%$ of GGS mothers are lone mothers. The total proportion of children living with lone mothers is likely to be slightly lower, since lone mothers on average have fewer children than mothers who are married or who live in a partnership. 
Table 1: Children and mothers by household type (2004)

\begin{tabular}{|c|c|c|}
\hline & $\begin{array}{l}\text { children by } \\
\text { household type* }\end{array}$ & $\begin{array}{l}\text { mothers by } \\
\text { household type }\end{array}$ \\
\hline 2 - parent household & $56 \%$ & $57 \%$ \\
\hline lone mother & $8 \%$ & $9 \%$ \\
\hline lone father & $0.4 \%$ & \\
\hline lone mother + relatives & & $11 \%$ \\
\hline 2 parents + relatives & & $24 \%$ \\
\hline relatives and/ or parents & $35 \%$ & \\
\hline
\end{tabular}

Another approach is to look at lone mother households as a proportion of all households. Lokshin, Harris, and Popkin (2000) find that the proportion of households led by single parents fluctuated between 7.5\% and nearly 9\% between the years 1992 and 1996. Thus, altogether, lone mother households represent a substantial proportion of households in Russia. The next section reviews their economic situation.

\section{Employment and the economic situation of lone mothers in Russia}

In the Soviet Union, a lot of effort was put into promoting high female labor force participation and into enabling mothers to be employed. Thus, lone mothers' freedom of choice of type of living arrangement might be expected to have been quite high. Access to employment and childcare should have guaranteed high personal autonomy, making it possible for lone mothers to support their children on their own for as long as they wanted. Then, after 1991, many childcare facilities were closed and full employment was no longer guaranteed. This new situation could have had the potential to exclude lone mothers from employment. However, important inequalities existed in the Soviet Union already. Also, far from dropping out of the labor market, lone mothers had employment rates that remained exceptionally high after the transition, despite greater obstacles. This section examines how the structure of the labor market and the institutional setting 
influenced lone mothers' economic situation before and after the political transition, highlighting continuities and changes.

\subsection{Female employment and labor force participation}

During Soviet times, female labor force participation was very high compared to other industrialized countries (Lokshin 2004). In the post-Soviet period, for ages $20-44$, female and male labor force participation rates remained almost equal according to figures provided by the United Nations Statistics Division (2007). On the other hand, it appears that women aged over 55 always had quite low labor force participation rates. This corresponds to a retirement age of 55 for women in the Soviet Union (Brainerd 2000). Part-time employment was hardly relevant at all in the Soviet Union. Less than 1\% of female employees were employed part-time (Lokshin 2004). At least officially, unemployment did not exist either. Thus, practically everyone who was in the labor force was employed full-time.

In the political transition period during the 1990s, unemployment rose to a level of almost $10 \%$, with little difference between men and women. While unemployment was not as severe as might have been expected, real wages strongly declined and workers were subject to wage arrears. The years since 2000 then witnessed signs of economic recovery, with rising real wages and a decline in unemployment rates (Lokshin 2004; Hansberry 2004; Federal State Statistics Service 2005). Part-time employment rates also increased in the transition period (Teplova 2007).

\subsection{Maternal employment rates}

While gender differences neither in employment rates nor in labor force participation rates seem to be very large, at least for younger men and women, there are important differences in employment rates between different groups of mothers. Table 2 shows estimates of mothers' employment rates by household type and by age of the youngest child, based on GGS data for 2004. We see that lone mothers are generally more likely to be employed full-time than mothers who are married or cohabiting. Very few mothers work while the youngest child is less than 1 year old; the majority is on maternity leave. 
Employment rates increase sharply as soon as the youngest child reaches age 3. This corresponds to the end of additional childcare leave. Other studies, referring to the mid1990s and the beginning of the $21^{\text {st }}$ century, likewise find higher employment rates for lone mothers in Russia than for married mothers (Teplova 2007; Kanji 2004; Lokshin 2004).

Table 2: Mothers' employment status by household type and age of the youngest child

\begin{tabular}{|c|c|c|c|c|c|}
\hline age of the youngest child & full-time & $\begin{array}{l}\text { employme } \\
\text { part-time }\end{array}$ & $\begin{array}{l}\text { status } \\
\text { maternityl } \\
\text { parental } \\
\text { leave }\end{array}$ & $\begin{array}{l}\text { non- } \\
\text { employed }\end{array}$ & Student \\
\hline \multicolumn{6}{|l|}{ lone parent household } \\
\hline 0 years & $2 \%$ & $0 \%$ & $64 \%$ & $34 \%$ & $0 \%$ \\
\hline 1 - 2 years & $34 \%$ & $2 \%$ & $33 \%$ & $31 \%$ & $1 \%$ \\
\hline 3 - 6 years & $68 \%$ & $3 \%$ & $0 \%$ & $25 \%$ & $1 \%$ \\
\hline 7 - 15 years & $78 \%$ & $2 \%$ & $1 \%$ & $16 \%$ & $1 \%$ \\
\hline all & $71 \%$ & $3 \%$ & $6 \%$ & $17 \%$ & $1 \%$ \\
\hline \multicolumn{6}{|l|}{ 2-parent household } \\
\hline 0 years & $4 \%$ & $1 \%$ & $65 \%$ & $23 \%$ & $6 \%$ \\
\hline 1 - 2 years & $21 \%$ & $4 \%$ & $45 \%$ & $28 \%$ & $2 \%$ \\
\hline $3-6$ years & $69 \%$ & $3 \%$ & $3 \%$ & $23 \%$ & $1 \%$ \\
\hline 7 - 15 years & $70 \%$ & $4 \%$ & $1 \%$ & $23 \%$ & $1 \%$ \\
\hline all & $57 \%$ & $4 \%$ & $13 \%$ & $23 \%$ & $1 \%$ \\
\hline
\end{tabular}

source: GGS 2004 (own calculations)

data is weighted to account for the sampling design

\subsection{The gender wage gap}

Besides employment rates, knowledge of the earnings structure is equally important to understand the economic situation of lone mothers in Russia. Several studies have found evidence that a gender wage gap comparable to western countries existed in the Soviet Union already (Brainerd 2000; Pascall and Manning 2000; Hansberry 2004; Newell and Reilly 1996). The gender gap in the monthly wage seems to have grown somewhat larger at the beginning of the 1990s (Brainerd 2000; van der Lippe and Fodor 1998; Trapido 2007; Ogloblin 1999; Newell and Reilly 1996). On the other hand, Pascall and Manning (2000) report little change in the monthly wage ratio between 1989 and 1996. Newell and Reilly (1996) estimate that the hourly wage ratio in 1992 in any case did not change 
compared to earlier periods. For the second half of the 1990s up to 2002, Hansberry (2004) finds moderate hourly female/male wage ratios of around $80 \%$, with a dip to $73 \%$ for the years 2000 and 2001.

Although the gender pay gap found for Russia both before and after 1991 is comparable to that in most western countries, wages at the beginning of the 1990s generally were not very high, as pointed out by Pascall and Manning (2000). This is likely to have made it very difficult for lone mother families to live on only one income.

\subsection{Earnings inequalities between women by education and occupation}

In this section we examine inequalities between different groups of female employees. This is important in order to understand which groups of lone mothers may be particularly subject to difficult economic circumstances.

Alexeev and Gaddy (1993) find evidence of generally moderate degrees of income inequality for the 1980s for the entire population. Their estimates give Gini coefficients of 0.29 in 1980 and 0.275 in 1989 for the entire Soviet Union, and 0.264 just for Russia in 1988. After the transition, overall income inequality increased strongly. The Russian Federal State Statistics Service reports a Gini coefficient of 0.387 for 1995 and 0.406 for 2004 (Federal State Statistics Service 2005).

For the present context however, wage inequality among women is of greater interest. Gustafsson et al. (2001) calculate a Gini coefficient of 0.206 for wages of female workers aged 25-55 in 1989 in Taganrog, considered to be a typical Russian industrial city. Their estimate of the Gini coefficient among women is smaller than their estimate of the Gini coefficient for men's and women's wages together, at 0.241. Education was found to significantly affect wages, even more so for women than for men. Women working as managers had the highest wages, followed by manual workers, then professionals, and finally office workers. Workers in transportation, trade and service, as well as public service had lower wages than workers in manufacturing or construction.

Several studies have analyzed changes in the impact of education on earnings in the transition period. Newell and Reilly (1999) find that returns to education increased across the early 1990s, but explain only a fraction of the general rise in inequality. These findings apply to men as well as women. Gerber and Hout (1998) also find increases in the effect of education on wages for women across the early 1990s, while they find no such 
effect for men. The authors additionally find that wages of professionals increased relative to skilled manual workers in general and relative to unskilled manual and non-manual workers in the state but not in the private sector. The wage advantage of managers relative to professionals also increased. Skilled manual workers were not able to improve their position relative to unskilled workers. Lower routine non-manual workers had the lowest wages during the whole study period. Further findings are that the cognitive sector lost relative to industry, but that the service sector has gained relative to the industrial sector. Wages in rural areas further declined relative to urban areas. After the transition, employment in the private sector also generally seems to have been associated with higher earnings, although advantages for women did not begin to appear until the mid-1990s.

Table 3 gives an overview of women's mean monthly earnings by occupation for the year 2004 based on GGS data. The second column shows which proportion of female employees were employed in a given occupational group. Here it can be seen that the group of female managers is extremely small, though in 2004 they continued to earn considerably higher wages than others. Professionals are the second highest earning group, closely followed by technicians, associate professionals, and plant and machine operators and assemblers. Clerks may have earned little before the transition, but that no longer seems to be as much the case. The lowest earning groups are agricultural workers and workers in elementary occupations, though the former group again is very small. Service and sales workers have the third lowest earnings.

Altogether, the studies reviewed in this section do indicate that important income differences existed between women with different levels of education and in different occupations even before the transition. These differences increased after 1990. Women who are managers had the highest incomes before and particularly after 1991. However, only an extremely small proportion of female employees are managers. The most relevant comparatively high income groups then are professionals, and before 1991, also skilled manual workers. A conclusion therefore is that lone mothers working in these occupations were likely to have had the least problems economically supporting their family. Before 1991, office workers had very low wages compared to others. They therefore may have been quite strongly affected by economic difficulties. It is likely that lower routine nonmanual workers were even more likely to have been affected by poverty, both before and after 1991. Professionals working in science and teaching are likely to have been faced with greater economic problems after 1991, as wages in cognitive branches declined relative to the industrial sector after 1991. 
Table 3

Women's mean monthly earnings by occupation (2004)

$\begin{array}{lrr} & \begin{array}{r}\text { mean earnings } \\ \text { (rubles) }\end{array} & \begin{array}{r}\text { Distribution of } \\ \text { female employees } \\ \text { across occupations }\end{array} \\ \text { legislators, senior officials, managers } & 5960 & 3 \% \\ \text { professionals } & 3758 & 21 \% \\ \text { technicians and associate professionals } & 3623 & 12 \% \\ \text { clerks } & 3304 & 8 \% \\ \text { service workers and shop and market sales workers } & 2856 & 13 \% \\ \text { skilled agricultural and fishery workers } & 1973 & 2 \% \\ \text { craft and related trade workers } & 3457 & 19 \% \\ \text { plant and machine operators and assemblers } & 3546 & 13 \% \\ \text { elementary occupations } & 1942 & 9 \%\end{array}$

source: GGS 2004 (own calculations), weighted to adjust for sampling design

\subsection{Poverty among lone mother households}

Despite lone mothers' exceptionally high employment rates, low part-time employment, and a gender wage gap that is not unusually large, households containing lone mother families have the highest poverty rates of all household types in Russia (Lokshin, Harris, and Popkin 2000; Kanji 2004; McKinney 2004). If wages are generally low, even comparatively small differences in earnings can contribute to large differences in poverty rates between lone mother households and other household types, as measured by absolute poverty measures. In addition, for those who have no work, support from alimony payments is likewise low. This often has to do with difficulties enforcing alimony payments or with the low level of men's own earnings (Pascall and Manning 2000; Kanji 2004). Contributions from state benefits have also been quite low. In the next section we review the development of family benefits, maternity leave regulations, and childcare provisions. 


\section{The development of family policy and the childcare infrastructure}

\subsection{The development of childcare provision}

Availability of childcare is especially important for lone mothers so they can work and possibly escape poverty. As a result of efforts to enable nearly universal full-time employment of women, childcare provision was very high in the Soviet Union. Major investments in the childcare infrastructure in Russia were made as early as the late 1920s (McKinney 2004; Teplova 2007). Overall provision rates of childcare dropped in the transition period, but they remained relatively high in international comparison (Pascall and Manning 2000; McKinney 2004). One reason for drops in pre-school attendance rates may have been rising costs (Oberemko 2006). Fees for childcare may have made it difficult for low-income households to afford such arrangements. As poverty rates are highest for lone mother households, fees may have posed a particular obstacle for them.

Nonetheless, even very recent data still indicate quite high attendance rates, as shown in Table $4 .{ }^{1}$ Use of formal childcare is highest for age groups 3-6. A total of $83 \%$ of lone mothers and 78\% of two-parent families with children in this age group use formal childcare (those who use formal childcare summed up with those who use formal childcare as well as childcare provided by relatives). Formal childcare is still used comparatively frequently for children aged 1-2 years (32\% for lone mothers and $24 \%$ for 2-parent families). It seems that there are very few formal childcare arrangements available for children aged less than 1 . Lone mothers in particular appear to rely heavily on relatives for childcare when their children are very young. Estimates of attendance rates from other sources generally give comparable results (Pascall and Manning 2000; McKinney 2004; Oberemko 2006; Lokshin 2004; Federal State Statistics Service 2005).

\footnotetext{
${ }^{1}$ Table 4 gives childcare arrangements for families all of whose children are within a specified age group. This is because it is not possible to determine which child the childcare was used for. A tabulation by age of the youngest child would have led to an overestimation of childcare for very young children, as older siblings of children aged less than 1 will often be in kindergarten.
} 
Table 4: Childcare arrangements by age of children and household type

\begin{tabular}{|c|c|c|c|c|}
\hline $\begin{array}{l}\text { all children are in age } \\
\text { group }\end{array}$ & $\begin{array}{l}\text { institutional } \\
\text { care only }\end{array}$ & $\begin{array}{l}\text { institutional + } \\
\text { relative care }\end{array}$ & $\begin{array}{l}\text { relative } \\
\text { care only }\end{array}$ & $\begin{array}{l}\text { no childcare } \\
\text { arrangement }\end{array}$ \\
\hline \multicolumn{5}{|l|}{ lone mothers } \\
\hline 0 years & $0 \%$ & $0 \%$ & $79 \%$ & $21 \%$ \\
\hline 1 - 2 years & $5 \%$ & $27 \%$ & $46 \%$ & $21 \%$ \\
\hline 3 - 6 years & $20 \%$ & $63 \%$ & $16 \%$ & $1 \%$ \\
\hline 7 - 15 years & $8 \%$ & $6 \%$ & $20 \%$ & $66 \%$ \\
\hline \multicolumn{5}{|l|}{ 2-parent households } \\
\hline 0 years & $0 \%$ & $0 \%$ & $61 \%$ & $39 \%$ \\
\hline 1 - 2 years & $12 \%$ & $12 \%$ & $45 \%$ & $31 \%$ \\
\hline 3 - 6 years & $25 \%$ & $52 \%$ & $13 \%$ & $10 \%$ \\
\hline 7 - 15 years & $5 \%$ & $6 \%$ & $17 \%$ & $71 \%$ \\
\hline
\end{tabular}

source: GGS 2004 (own calculations), weighted to adjust for sampling design

\subsection{Family benefits}

Families in Russia have access to a number of different types of allowances, many of which existed in the Soviet era already. In 1998, however, many benefits were restricted to low-income families. Lone mothers have been entitled to special benefits for the first, second, and third child since the late 1940s. Even up through the 1980s, though, the levels of these payments remained unchanged and were quite low in real terms. In 1990 then, they were linked to the minimum wage. Since 2001, lone mothers can deduct twice the regular amount per child from taxation. Lone mothers also receive twice the regular child allowance (McKinney 2004; Pascall and Manning 2000; Rieck 2006; Teplova 2007; Generations and Gender Contextual Data Base 2007). Altogether, real values of benefits have often been nearly negligible, however (Pascall and Manning 2000; Kanji 2004).

\subsection{Maternity and childcare leave}

In the Soviet Union, since 1970, maternity leave ran from 56 days before until 56 days after the birth of the child, during which time full wages were paid. Maternity leave was extended to 70 days before and 70 days after birth in 1995. Full wage compensation continues to be paid during this time. Unemployed women receive a benefit that is linked 
to the minimum wage, and for students, it is linked to the height of scholarships (Teplova 2007; Generations and Gender Contextual Data Base 2007).

Childcare leave begins at the end of maternity leave. In the 1980s, childcare leave was partially paid from the end of maternity leave up until the child's $1^{\text {st }}$ birthday. Further unpaid leave ran until the child was 18 months old. In 1989, partially paid leave was extended until the child was 18 months old. During partially paid leave, parents receive a care-giving allowance from social insurance funds. This allowance however has not been very high, amounting to less than $10 \%$ of the poverty line. Additional leave during which parents receive a low-level flat-rate benefit from their employers runs from the time the child is 18 months old until the child reaches age 3 . This benefit is even lower than the care-giving allowance paid up to the end of the first 18 months (Teplova 2007; Generations and Gender Contextual Data Base 2007). Pascall and Manning (2000) report that the real value of leave benefits decreased sharply between 1990 and 1991, and varied only slightly between 1991 and 1997.

In combination, childcare and leave provisions do not seem to be very well adapted to the situation of lone mothers with very young children. Although childcare leave runs until the child is 18 months old, the amount of payment is far from sufficient as a primary source of income. Furthermore, institutional childcare is not yet available either until children are older than 18 months. Almost all lone mothers are on leave while their child is still less than 18 months old. Therefore, lone mothers with very small children would have to rely on financial support from relatives during this time.

\section{A comparison with the economic situation of lone mothers in other countries}

Lone mothers' economic situation in Russia, with high employment rates coupled with high poverty rates, does not seem to be so exceptional in international comparison. For example, in Japan, while lone mothers' employment rates are exceedingly high, their incomes rank very low compared to other household types. This appears to be related to a large gender wage gap as well as to low levels of transfer payments (Ezawa and Fujiwara 2005). Likewise, in the United States, lone mothers' employment as well as their poverty rates had been quite high in international comparison even before the implementation of welfare reforms in the second half of the 1990s (Rowlingson and Millar 2002). These reforms limited the cumulative duration that families could receive assistance payments, 
and required parents to engage in employment, training, or job search activities early on during assistance receipt (Corcoran et al. 2000). After the implementation of these reforms, lone mothers' employment rates increased substantially and poverty rates fell to some extent. The relative importance of the policy reform and of favorable economic conditions for these developments has been the subject of a controversial debate (Christopher 2004; Cherry 2007; Christopher 2007). Although altogether poverty rates among lone mothers fell across the late 1990s, they still remain comparatively high (Christopher 2007).

While in Russia, Japan, and the United States, lone mothers' employment and poverty rates are simultaneously high, in another set of countries including Australia, the Netherlands, and Germany, employment rates among lone mothers tend to be quite low. In the Netherlands and Australia, poverty rates among children of non-employed lone parents, while lower than in the United States, were still reported to be around $40 \%$ (Rowlingson and Millar 2002). For the year 2000, the percentage of lone mothers of children aged 0-10 depending on transfer payments as their main source of income was estimated to be $46 \%$ in western Germany and $62 \%$ in eastern Germany. A greater part of transfer payments was accounted for by social assistance payments in western Germany, and by unemployment insurance in eastern Germany (Konietzka and Kreyenfeld 2005). Reasons for lone mothers' lower employment rates in this second set of countries may be less access to childcare, and perhaps greater eligibility for and slightly higher levels of transfer payments. Neither the conditions in the first nor the second set of countries seem to be very effective in bringing lone-parent families above the poverty line or rendering them economically independent, however.

In Great Britain, lone parents' employment rates have in the past been very low in international comparison (Rowlingson and Millar 2002). In 1999, the Working Families' Tax Credit (WFTC) was introduced, a reformed version of previous programs to supplement low earnings for working parents. ${ }^{2}$ The WFTC strengthened work incentives by raising the earnings threshold up to which parents are eligible for the full benefit, and, for those earning in excess of the threshold, by cutting back the reduction of the supplement from $70 \%$ to $55 \%$ of earnings in excess of the threshold (Dilnot and McCrae 2000). A particularly interesting element of WFTC is a relatively large contribution to covering childcare costs for working low-income families (Rake 2001). An important

\footnotetext{
${ }^{2}$ The WFTC was replaced by Working Tax Credit and Child Tax Credit in April 2003 without major changes to the aspects mentioned above (Inland Revenue 2002; Rake 2001; HM Revenue \& Customs 2008).
} 
difference between the introduction of the WFTC in Great Britain and the welfare reform in the United States is that in Great Britain incentives to work were strengthened without increasing sanctions. Evidence has been found that the introduction of the Working Families' Tax Credit, particularly the contribution to covering childcare costs, led to an increase in employment rates among lone mothers (Francesconi and van der Klaauw 2004; Brewer et al. 2005). Child poverty in Great Britain also appears to have declined after the introduction of the WFTC (Brewer et al. 2005). A further interesting finding by Francesconi and van der Klaauw (2004) is that the introduction of the WFTC seems to have had the unintended effect of reducing partnership formation and fertility rates among lone mothers in Great Britain. In the present study, a negative relationship between lone mothers' employment and partnership formation rates is likewise expected.

While in Great Britain there seems to have been some improvement in employment opportunities for lone mothers, lone parents already appear to have achieved both high employment and low poverty rates in a few countries. This seems to be the case for instance in France and in Norway, due especially to a good childcare infrastructure, relatively high wage levels, as well as transfer payments both to working and non-working parents (Rowlingson and Millar 2002).

For Russia, it remains to be seen whether lone mothers' high employment rates, together with the comparatively high level of childcare provision, will eventually lead to lower poverty rates among lone mothers as incomes generally rise. In the following however, the aim is to investigate how lone mothers' economic situation affected their processes of partnership formation both before the political transition and in the first decade thereafter. As we have summarized above, lone mothers' economic situation has been found to be very difficult in many countries. The research question investigated in the following, of whether lone mothers' economic situation limits their freedom of choice of type of living arrangement by pressuring them to enter new partnerships sooner than they would under other conditions, may therefore apply to many other countries as well.

\section{Research questions}

Our main research questions refer to the influence of education and employment on a lone mothers' entry into a new partnership in Russia. As discussed above, previous research has shown that poverty rates are higher among lone mother households than among all 
other household types. Although full-time employment rates of lone mothers in Russia are very high, at $71 \%$ compared to $57 \%$ of mothers in two-parent households (Table 2), it seems that many lone mothers' earnings are not high enough to bring their families above the poverty line. Child benefit payments, which could in principle alleviate economic difficulties, have been very low in real terms. For some, childcare will also have become too expensive to afford. Thus, many lone mothers' extremely difficult economic situation may have put them under strong pressure to enter a new partnership quickly.

The line of argumentation here is that partnership formation may be one way to escape an extremely difficult economic situation. If this proves to be the case, it would be an exception to general patterns of partnership formation. Many empirical studies have tested the theory, often attributed to Becker (1993), that women with higher earnings potential are less prone to marry, because they have less to gain from gender-specific labor divisions within households. However, as pointed out by Köppen (2008), empirical tests of this theory give very varied results. Some authors have argued that negative effects of women's earning potential should only be found in countries with a very traditional gender division of labor. In countries where marriage does not generally affect women's labor force participation, as is the case for most contemporary western societies, there should not be a negative effect (Ono 2003; Sweeney 2002; Duvander 1999). Correspondingly, most empirical studies have found either no effects or positive effects of women's educational attainment and economic situation on propensities to marry (Santow and Bracher 1994; Hoem 1986; Xie et al. 2003; Ono 2003; Blossfeld and Huinink 1991). Positive, very small, or non-significant effects have also been found for entry into cohabitation, in countries where, as expressed by Bracher and Santow (1998), cohabitation has become a conventional type of union (Hoem 1986; Bracher and Santow 1998; Liefbroer and Corijn 1999). In some countries, there seems to be evidence of a change in the direction of effects of women's educational attainment and economic situation from negative to positive as gender roles have become more egalitarian (Okun 2001; Luxán et. al. 1999; Goldstein and Kenney 2001). Japan seems to be an exception, with a clear negative effect of women's income, and Ono (2003) attributes this to the very differentiated gender roles among married Japanese men and women. Some studies have also found negative effects of women's economic potential on marriage for countries where weak or positive effects are generally found, such as Germany or the United States (Brüderl and Diekmann 1994). 
Thus, women with lower earnings potential do not generally seem to have higher propensities to form partnerships. Particularly in countries where women's labor market participation is high even after marriage, no effects or positive effects are usually observed. Russia is a country with very high female labor force participation, both among single women and among those who are married or are mothers. Thus, in general, I would not expect a negative effect of women's education or earnings potential on entry into a partnership. However, the situation may be different for women facing extreme economic difficulties. Faced with poverty, some women may be under strong pressure to form a partnership sooner than they would under other circumstances. This would imply a loss of freedom of choice of type of living arrangement.

Lone mothers are more likely to be faced with poverty than childless women with the same earnings. This is because of their larger household size and childcare costs. Therefore, they should more often be subject to economic pressure to enter new partnerships. Thus, in principle, lone mothers in low-paying occupations should have higher rates of partnership formation than childless women in the same low-paying occupations.

On the other hand, certain constraints with respect to partnership formation that are relevant for lone mothers do not apply to childless women. In particular, potential partners may be reluctant to take on responsibility as step-fathers. In addition, mothers with small children or many children may have very little time to get to know potential partners. Thus, there are important obstacles for lone mothers that could substantially lower their rates of partnership formation compared to childless women.

Therefore, differences in the economic pressure to form new partnerships are unlikely to show up in direct comparisons of lone mothers and childless women. On the other hand, comparing lone mothers with very low earnings to lone mothers with higher earnings could reveal higher rates of partnership formation for those most subject to poverty.

Unfortunately, longitudinal information on earnings was not available in the data available to us, so various indicators of earnings will be applied in the empirical analyses. A first hypothesis is that lone mothers with high levels of education can be expected to have lower partnership formation rates. As described in section 3.4, education has been found to affect women's earnings in Russia, even before the transition. Lone mothers with a high education can therefore be expected to be more likely to have an income high enough to evade poverty. 
Highly skilled occupations did not uniformly lead to higher earnings, especially before 1991. As reviewed in section 3.4, qualified manual workers had at least as high or higher earnings than women working as professionals. This may have changed somewhat after 1991. What did not change is the disadvantaged position of low-skilled non-manual workers and service workers. Lone mothers working in these occupations are likely to have been particularly subject to poverty both before and after 1991. Thus, the hypothesis is that they will uniformly have higher rates of partnership formation than other groups. Before 1991, office workers also appear to have had quite low earnings, which may also have influenced their rates of partnership formation.

The hypothesis for the effect of employment status is that lone mothers who are employed have lower transition rates into a new partnership than those who are not employed. Nearly all lone mothers were employed before the transition. Although employment rates remained high after 1991, unemployment did begin to emerge, as well as exits from the labor market. Those lone mothers who were not employed are likely to have been faced with serious economic problems, because of weak systems of social support. For some, increasing costs of childcare will have made reemployment difficult. Therefore, an effect of employment status on rates of transition into a new partnership is expected, especially after the transition.

\section{Data and method}

The data that was used to test these hypotheses is from the Russian Generations and Gender Survey (GGS), and from the corresponding Education and Employment Survey (EES). The Russian GGS data was collected by the Independent Institute of Social Policy (Moscow) in 2004. It contains complete fertility and partnership histories. The EES, conducted in 2005, is a follow-up for a sub-sample of the GGS. The EES contains complete education, employment, and migration histories. For the following analyses, these were combined with the fertility and partnership histories from the GGS. ${ }^{3}$

\footnotetext{
${ }^{3}$ The Russian GGS was conducted by the Independent Institute of Social Policy (Moscow) with the financial support of the Pension Fund of the Russian Federation and the Max-Planck-Gesellschaft, Germany. The design and standard survey instruments of the GGS were adjusted to the Russian context by the Independent Institute of Social Policy (Moscow) and the Demoscope Independent Research Center (Moscow) in collaboration with the Max Planck Institute for Demographic Research (Rostock, Germany).
} 
In order to incorporate effects of time-varying variables, such as level of education, employment status, or the age of the youngest child, the method of analysis chosen is event-history analysis. Here, the dependent variable is the risk (intensity) of partnership formation. Respondents come under risk as soon as they become lone mothers. Episodes are censored when the youngest child reaches age 15, or when all children have moved out of the household. During the study period, there were 673 partnership formations. Altogether, there were 1775 spells of lone motherhood and 1527 corresponding respondents, as some respondents were single mothers more than once. Clustering was accounted for in our analyses, but this did not alter the results. Kish weights were used to account for the household sampling design. Separate models for the risk of partnership formation were estimated for childless women as well, in order to provide a basis of comparison for the estimates for lone mothers.

\section{Empirical results}

This section begins by presenting descriptive results on the duration of lone motherhood in Russia. Differences in risks of partnership formation between lone mothers and childless women as well as effects of demographic factors are then analyzed. Subsequently, the influence of education and employment characteristics is examined. As we have described above, it is likely that lone mothers face important obstacles with respect to partnership formation. On the other hand, given lone mothers' high poverty rates and their responsibility of providing for their children, some may be faced with strong pressure to begin a new partnership sooner than they would prefer under other circumstances. If this is the case, level of education, employment status, and occupation should affect partnership formation rates among lone mothers. Given increasing inequality after the transition, these effects are expected to have grown stronger after 1991.

\subsection{The duration of lone motherhood. Descriptive results}

Divorce rates in Russia increased across time, and thus for recent cohorts of women, it has also become more common to experience lone motherhood. Lone mothers may have been 
a more marginalized group in older than in younger cohorts, with corresponding greater difficulties of finding new partners. Thus, it seems plausible to expect durations in lone motherhood to have been longer in older than in younger cohorts. Figure 1 shows that for women who became lone mothers at young ages, durations in lone motherhood were indeed slightly shorter in younger than in older cohorts. In both cohorts 1950-59 and 1960-69, the median duration of lone motherhood was 5 years, while it was only 4 years in the cohort from 1970-85.

For women who became lone mothers at somewhat older ages, namely at ages 26 30 , durations in lone motherhood generally seem to be longer, as shown in Figure 2. For cohort 1950-59, the median duration is 6.5 years, and for cohort 1960-69, even after 10 years, not half had yet exited lone motherhood. For the youngest cohort, born in 1970-85, the length of the observation period is not long enough to be able to say anything conclusive about median durations in lone motherhood. For women who became lone mothers at ages 26-30 then, at least judging from the first two cohorts, the development is in the opposite direction from what was expected. Durations in lone motherhood have become longer across cohorts, not shorter.

Figure 1: Duration of lone motherhood for women who were younger than 26 at the beginning of lone motherhood

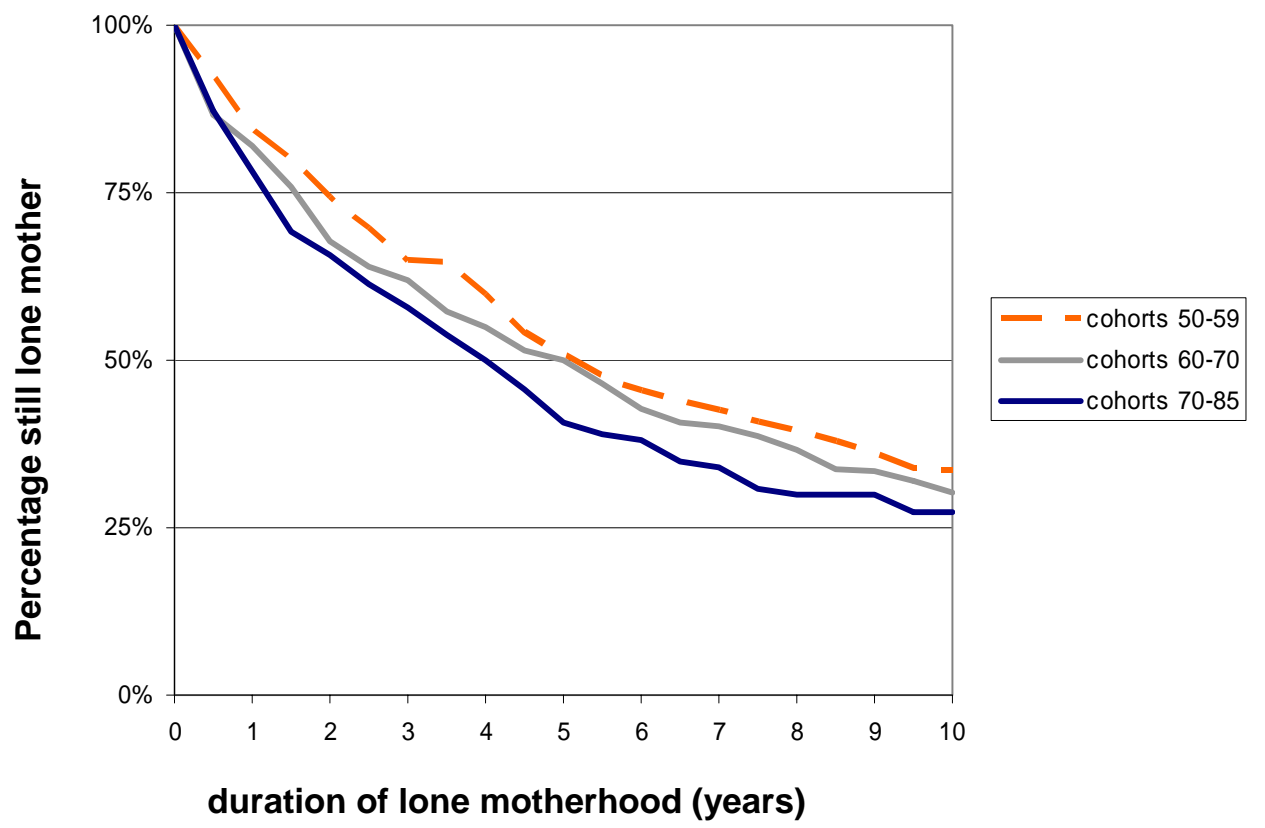


Figure 2: Duration of lone motherhood for women aged 26-30 at the beginning of lone motherhood

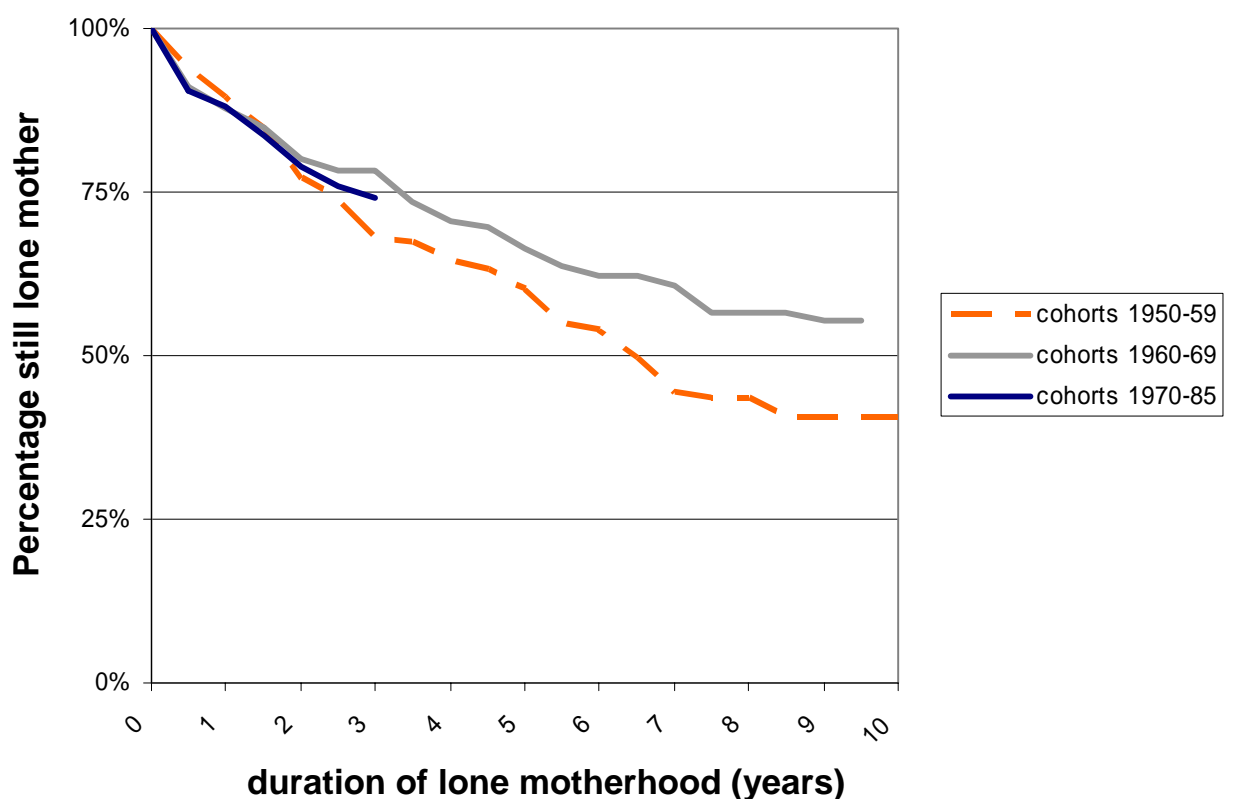

\subsection{Demographic factors influencing partnership formation among}

lone mothers and childless women; a comparison

The descriptive results presented above indicate that durations in lone motherhood are quite long. This impression can also be gained from looking at risks of partnership formation in a comparative perspective. The results presented in Table 5 show that lone mothers' risks of partnership formation are lower than those of childless women, particularly for those who have not lived with a partner. It is possible that they constitute a select group with lower propensities to form stable partnerships.

Table 5: Relative risks of partnership formation Interaction between parenthood and previous partnership

\begin{tabular}{l|c|c} 
& no previous partner & with previous partner \\
\hline childless women & 1 & 1.07 \\
lone mothers & $0.48 * \star \star$ & $0.89 *$
\end{tabular}

$* * *: p<0.01 ; * *: 0.01 \leq p<0.05 ; *: 0.05 \leq p<0.1$

Control variables: age, year, pregnancy, education, activity status, settlement size, religious denomination 
Another explanation might be that the negative effect of having no previous partner applies especially to very young lone mothers. Very young lone mothers without a previous partner might continue to live with their parents for longer durations of time than women of their age without children, and for that reason they may be less likely to meet a new partner. However, as Figure 3 shows, this is not the case. Very young lone mothers (aged 17-19) without a previous partner have the highest risks of partnership formation of all. Only above age 20 do lone mothers without a previous partner have lower risks of partnership formation than the other three groups. An explanation for very young lone mothers' exceptionally high risks of partnership formation could be that they are planning to form a common household with their partner, and have only briefly delayed entering the partnership.

Figure 3: Relative risk of partnership formation.

Interaction between age, previous partnership, and parenthood status

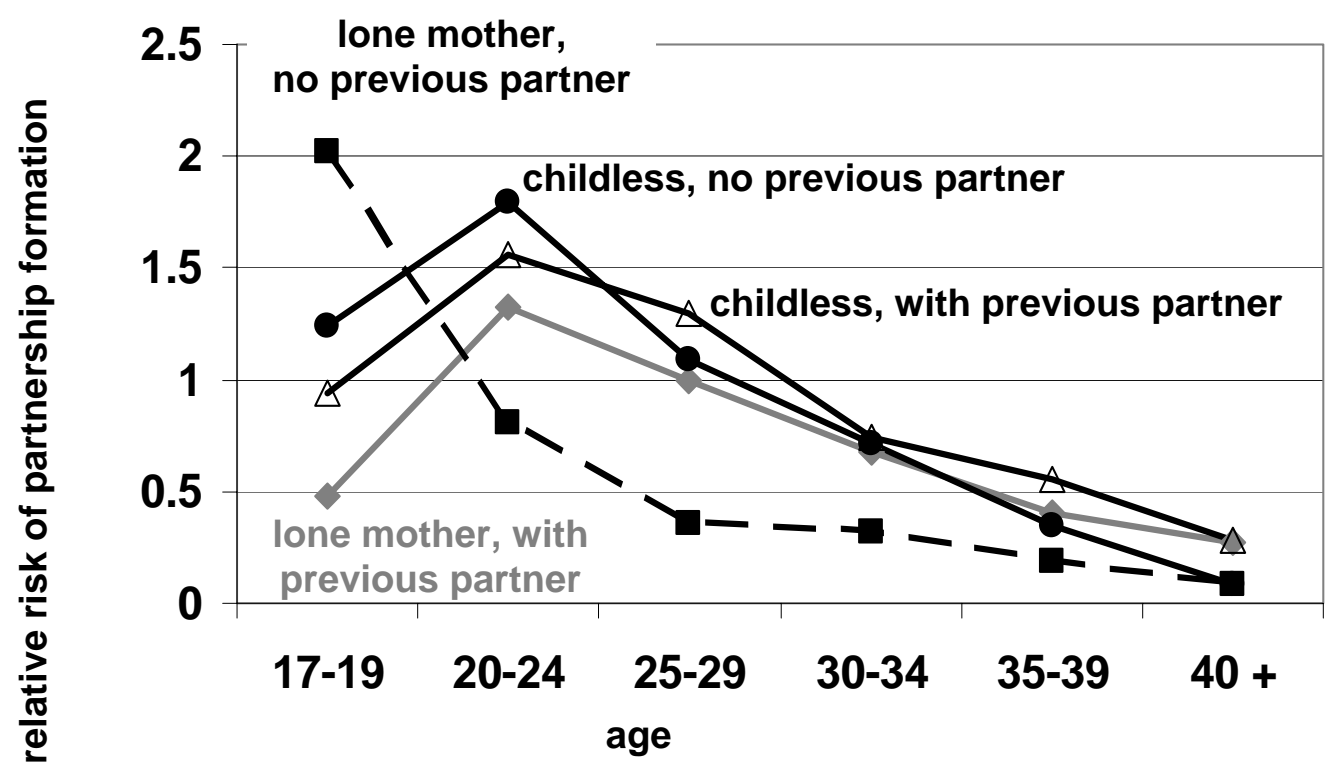

Control variables: year, pregnancy, education, activity status, settlement size, religious denomination

Further evidence that lone mothers' responsibility for their children is an obstacle for partnership formation is given by the estimates for Model 1 in Table 6. As expected, mothers of three or more children were found to have particularly low partnership 
formation risks. For them, risks of partnership formation are less than a third as high as for mothers of only one child. Mothers of very young children also seem to have much lower risks of partnership formation than do mothers of older children. 
Table 6: Relative risks of partnership formation for lone mothers and childless women

Model 1: lone mothers Model 2: childless women

\begin{tabular}{|c|c|c|c|c|}
\hline $\begin{array}{l}\text { Constant } \\
\text { number of children }\end{array}$ & 0.0059 & & 0.0091 & \\
\hline 1 child & 1 & & & \\
\hline 2 children & 0.86 & & & \\
\hline $3+$ children & 0.31 & 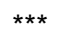 & & \\
\hline \multicolumn{5}{|l|}{ age of the youngest child } \\
\hline $0-1$ years & 1 & & & \\
\hline 2 - 4 years & 1.13 & & & \\
\hline 5 - 9 years & 1.41 & ** & & \\
\hline \multicolumn{5}{|l|}{ duration since last partnership } \\
\hline no previous partner & 1 & & 1 & \\
\hline $0-1$ years & 1.93 & $* \star *$ & 1.22 & * \\
\hline 2 - 3 years & 1.36 & $\star \star *$ & 1.20 & \\
\hline 4 - 5 year & 1.87 & 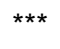 & 0.92 & \\
\hline $6-7$ years & 1.54 & $\star *$ & 0.94 & \\
\hline $8+$ years & 1.31 & & 0.55 & $\star \star \star ~$ \\
\hline \multicolumn{5}{|l|}{ Pregnancy } \\
\hline Pregnant & 3.63 & $\star \star \star *$ & 8.63 & $* \star *$ \\
\hline not pregnant & 1 & & 1 & \\
\hline \multicolumn{5}{|l|}{ Age } \\
\hline 17-19 & 3.38 & $\star \star \star *$ & 1.13 & * \\
\hline $20-24$ & 1.55 & $\star * *$ & 1.61 & 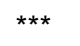 \\
\hline $25-29$ & 1 & & 1 & \\
\hline $30-34$ & 0.70 & $\star \star \star *$ & 0.66 & $* \star \star$ \\
\hline $35-39$ & 0.38 & $\star \star \star *$ & 0.50 & $\star \star \star *$ \\
\hline $40+$ & 0.22 & $* \star *$ & 0.26 & 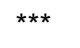 \\
\hline \multicolumn{5}{|l|}{ Period } \\
\hline $1966-79$ & 0.78 & & 0.97 & \\
\hline $1980-84$ & 0.96 & & 1.24 & $\star \star \star *$ \\
\hline $1985-91$ & 0.96 & & 1.25 & 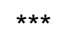 \\
\hline 1992-1999 & 0.86 & & 1.08 & \\
\hline $2000-04$ & 1 & & 1 & \\
\hline \multicolumn{5}{|l|}{ Education } \\
\hline no secondary degree & 0.67 & $\star *$ & 1.13 & \\
\hline secondary degree & 1 & & 1 & \\
\hline post-secondary degree & 0.87 & & 1.17 & $* \star *$ \\
\hline \multicolumn{5}{|l|}{ Activity status } \\
\hline full-time employed & 1 & & 1 & \\
\hline part-time employed & 1.27 & & 0.89 & \\
\hline non-employed & 1.33 & * & 1.15 & * \\
\hline in education & 0.96 & & 0.65 & 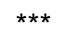 \\
\hline \multicolumn{5}{|l|}{ Place of residence } \\
\hline center of region, territory, or republic & 1 & & 1 & \\
\hline other town/ city & 0.96 & & 1.11 & $\star \star$ \\
\hline urban-type village & 1.28 & & 1.15 & * \\
\hline \multicolumn{5}{|l|}{ religious denomination } \\
\hline Orthodox & 1 & & 1 & \\
\hline Islam & 0.55 & * & 0.75 & $\star \star \star *$ \\
\hline Other & 1.03 & & 1.06 & \\
\hline Log pseudolikelihood & -1540.4 & 334 & -468 & .8344 \\
\hline
\end{tabular}


A potential problem in interpreting model 1 in Table 6 is that not all value combinations for the variables 'age of the youngest child', 'duration since last partnership', and 'age' are possible (Hoem 2000). For example, very few women whose last partnership ended eight or more years ago have a child aged 0-1, and no-one who is 17-19 years old has a child aged 10-14. Thus, a direct interpretation of the effect of having a child aged 10-14 compared to having a child aged 0-1 is only possible for older mothers who ended their last partnership only recently. ${ }^{4}$ Table 7 aids in interpreting the estimates shown in Table 6 by calculating relative risks for some examples of possible value combinations. For instance, Table 7 shows that, within one age group, a young age of the youngest child combined with a short duration since the last partnership on the one hand, and long durations since the last partnership combined with an older age of the youngest child on the other hand, result in very similar risks of partnership formation. Expanding the comparison across age groups, Table 7 shows that compared to older women with longer durations since last partnership, risks of partnership formation are clearly higher for young women with short durations since the last partnership, even when they have very small children.

Table 7

Calculations of relative risks using the estimates shown in Table 6

\begin{tabular}{|c|c|c|c|c|c|}
\hline & \multicolumn{5}{|c|}{ age of the youngest child (years) } \\
\hline & $\begin{array}{l}\text { duration since } \\
\text { last partnership }\end{array}$ & $0-1$ & $2-4$ & $5-9$ & $10-14$ \\
\hline & 0 - 1 years & 2.21 & 2.5 & 3.12 & \\
\hline \multirow[t]{4}{*}{ age $20-24$} & $2-3$ years & 1.56 & 1.76 & 2.2 & \\
\hline & 4 - 5 years & & 2.42 & 3.03 & \\
\hline & $6-7$ years & & & 2.49 & \\
\hline & $8+$ years & & & & \\
\hline \multirow{5}{*}{ age $30-34$} & 0 - 1 years & 1 & 1.13 & 1.41 & 1.65 \\
\hline & $2-3$ years & 0.7 & 0.8 & 0.99 & 1.16 \\
\hline & 4 - 5 year & & 1.09 & 1.37 & 1.6 \\
\hline & $6-7$ years & & & 1.13 & 1.32 \\
\hline & $8+$ years & & & 0.96 & 1.12 \\
\hline
\end{tabular}

\footnotetext{
${ }^{4}$ The model is nonetheless identifiable. Even if everyone whose youngest child is $0-1$ ended their previous partnership 0-1 years ago, a duration of 0-1 years since the previous partnership can coincide with any age of the youngest child.
} 
When we compare patterns of partnership formation between lone mothers and childless women (Model 1 and Model 2 in Table 6), it seems that many background factors have effects in similar directions, though they often are different in strength. Pregnancy for instance has a strong effect on risks of partnership formation for both lone mothers and childless women, but the effect is much stronger for childless women. An interpretation may be that lone mothers' options with respect to partnership formation are more constrained, so that pregnancy cannot raise risks of partnership formation to the same degree as for childless women. Partnership formation rates are higher among those living in smaller settlements, both among lone mothers and among childless women. This is a bit surprising, since it is often held that larger settlement sizes are associated with the opportunity to meet a larger number of potential partners, so that risks of partnership formation should be higher there. Risks of partnership formation appear to be generally lower among Muslim than Orthodox women, especially for lone mothers. One explanation may be that entries into cohabiting unions, which compose a large proportion of partnerships overall, are lower among Muslim than Orthodox women.

\subsection{The impact of education on risks of partnership formation}

The results in Table 6 show that education does not have quite the impact that was expected. The hypothesis was that lone mothers with high levels of education should have lower risks of partnership formation, as they on average have higher earnings and are better able to support their family on the basis of their own income. Lone mothers with a post-secondary degree ${ }^{5}$ do have somewhat lower risks of partnership formation than those with only secondary degrees. However, this effect is not significant. Among childless women, those with a post-secondary degree even have slightly higher risks of partnership formation than those with only a secondary degree. An explanation may be that childless women with only secondary degrees are still planning to continue their education and to earn a post-secondary degree, and thus are still postponing partnership formation. By contrast, very few lone mothers are still in education or return to education later on. Thus, among lone mothers, those who have a secondary degree will generally already have

\footnotetext{
${ }^{5}$ Here, the definition of post-secondary degrees includes degrees from secondary special schools, vocational colleges, and universities.
} 
reached their highest level of education. They are likely to have more limited labor market opportunities than those with a post-secondary degree. The results presented in Table 6 also show that, among lone mothers, those with less than a secondary degree have the lowest risks of partnership formation. This is in contrast to the hypothesis of a negative effect of education on risks of partnership formation. However, this finding should perhaps not be over-interpreted, as the group of lone mothers who have less than a secondary degree is extremely small.

\subsection{The impact of employment characteristics on}

\section{risks of partnership formation before and after 1991}

This section investigates whether the effects of occupation and employment status have changed after 1991. In the transition period after 1991, the strong drops in wages are most likely to have resulted in severe economic difficulties for people in the lowest-income occupations. These are employees in service and unskilled occupations. Table 8 shows that risks of partnership formation are substantially higher for lone mothers in service occupations than for university-educated professionals or managers both before and after 1991. Risks of partnership formation did increase slightly for lone mothers employed in service occupations after 1991, though not as strongly as expected. In contrast to what was expected, risks of partnership formation for lone mothers employed as unqualified workers remained unchanged after 1991. Their risks of partnership formation are among the lowest of all occupational groups, both before and after 1991.

It is interesting that lone mothers who are office employees have comparatively high risks of partnership formation before 1991, and lower risks after 1991. The development is opposite that for lone mothers working in qualified manual occupations. These changes correspond to findings by Gerber and Hout (1998) that skilled manual workers experienced a decline in earnings across the first half of the 1990s, while upper routine non-manual employees were able to increase their income.

A further change after 1991 was that unemployment began to occur. Before 1991, at least officially, there was practically no unemployment. Non-employment likewise was very rare. In the transition period, unemployment did not reach very high levels in international comparison, remaining at around 10\% throughout the 1990s (section 3.1). Nonetheless, the unemployed do compose a new labor market group that needs to be taken 
account of. Unemployment is likely to have been associated with severe economic difficulties in the 1990s, especially since social support institutions were not well funded. Lone mothers outside the labor market will likewise have faced problems of low incomes, since both alimony and parental leave payments were extremely low (section 4). In the models estimated here, those who were unemployed and those who were outside the labor market were combined into a 'non-employment' category. This is both because the economic situation of both groups is likely to be similar, and also because there is often a lot of hidden unemployment among mothers. It is probable that it was very difficult for non-employed lone mothers to support their families. Thus, they may have been subject to strong economic pressure to begin a new partnership quickly. The hypothesis therefore was that after 1991, lone mothers who are not employed have higher risks of partnership formation than those who are employed full-time. Before 1991, non-employment is not expected to be a very important factor. The results show that after 1991, non-employed lone mothers do have substantially higher risks of partnership formation than those working in most occupational groups (Table 8). Risks of partnership formation are about equally high for the non-employed as for those working in service occupations. Before 1991, risks of partnership formation are also relatively high for non-employed lone mothers, but this group is very small, and differences to lone mothers working in different types of occupations are not significant.

While labor market characteristics do seem to influence risks of partnership formation among lone mothers, there are only very weak effects of occupation and employment status among childless women in both time periods. This may indicate that the economic situation only begins to influence the propensity to enter a new partnership as soon as it falls below a certain threshold. Because of their larger household size and because of costs of childcare, disposable per capita household income is smaller for lone mothers than for childless women who otherwise have the same labor market characteristics. Among childless women, the only larger effect that is found is for those who are still in education. Childless women who are still in education have much lower risks of partnership formation than others. This corresponds to findings for many other countries. 
Table 8

Relative risks of partnership formation: interaction between occupation and time period

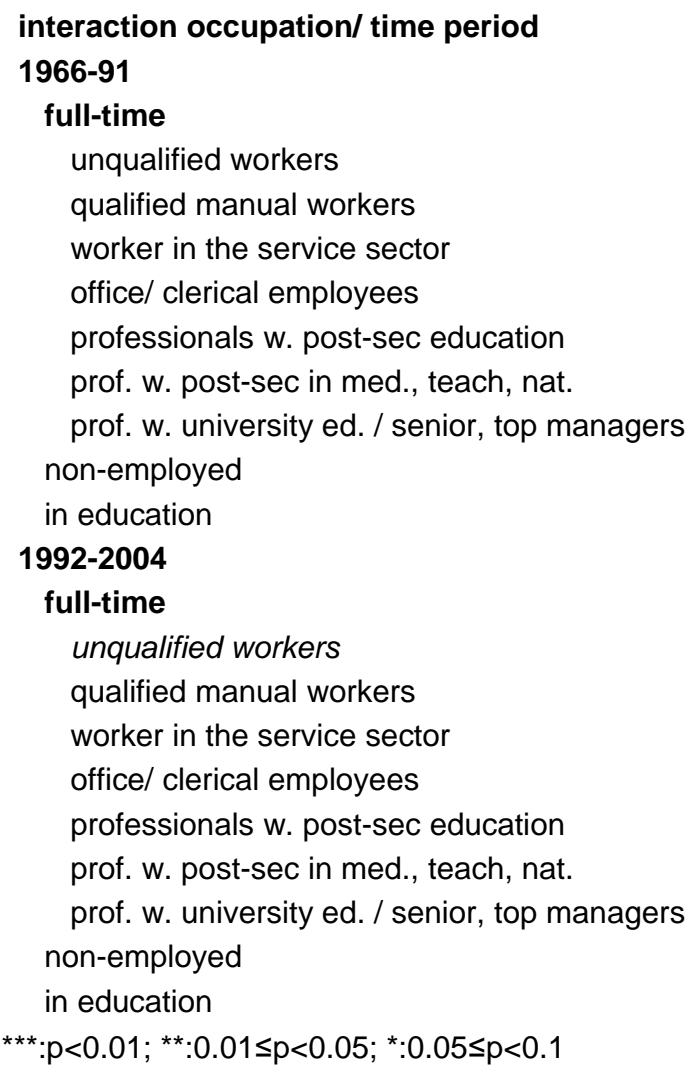

Model 1: lone mothers

Model 2: childless women

Control variables: age, pregnancy, education, part-time employment, settlement size, religious denomination, number of children, age of the youngest child, duration since last partnership

\section{Conclusions}

In this study we have investigated whether, when faced with very difficult economic situations, lone mothers enter new partnerships more quickly than in other circumstances in the Russian context. To provide a basis of comparison and to identify particularities of lone mothers' patterns of partnership formation, models for transitions into new partnerships were estimated for childless women as well. Effects of employment status and occupation on rates of transition into new partnerships were found to be greater for lone mothers than for childless women. This is remarkable, especially against the background of lone mothers' greater obstacles with respect to partnership formation. In general, rates of transition into new partnerships proved to be lower for lone mothers, 
particularly for lone mothers without a previous partnership, than for childless women. Possible reasons for their reduced rates of transition into new partnerships are time constraints and childcare responsibilities. Negative effects of having very young children and of having many children on rates of transition into new partnerships were found, further supporting this interpretation.

The main question that was investigated in this study is whether, despite these obstacles with respect to partnership formation, difficult economic situations nonetheless raise lone mothers' rates of partnership formation. This would indicate a loss of freedom of choice of type of living arrangement for lone mothers with low or no earnings. Employment rates of lone mothers in Russia have remained very high even after the transition in 1991. For many lone mothers, their income has not been high enough to escape poverty, however. Evidence of elevated rates of transition into new partnerships for low income groups was mixed. In contrast to the hypothesis, the group with the lowest earnings (namely the unqualified workers), were among those with the lowest rates of partnership formation. Patterns of partnership formation for the other occupational groups were more in line with the hypothesis, with a generally negative relationship between average earnings and rates of partnership formation. Lone mothers employed in service sector occupations, a group at the lower end of the earnings distribution, in particular had very high rates of partnership formation. While the relationship between earnings and lone mothers' rates of partnership formation is thus unclear, the hypothesis with respect to a positive effect of non-employment on rates of partnership formation was supported. An explanation for this effect may be that many non-employed lone mothers were unable to work due to lack of childcare. Although the level of childcare provision in Russia is still quite high in international comparison, access to childcare is far from universal. Lone mothers generally have very little access to non-employment income, given very low levels of parental leave benefits and alimony payments. Some non-employed lone mothers may therefore have chosen to begin a new partnership as one way of escaping poverty.

The empirical findings can to some extent be taken to support the hypothesis that lone mothers in very difficult economic situations enter new partnerships sooner than they would otherwise prefer. There may of course be other explanations for the elevated rates of partnership formation among non-employed lone mothers and among lone mothers in low-income service-sector occupations. Further unobserved factors could be responsible for these effects. For example, non-employed lone mothers could be less career and more family oriented. Forming a new partnership might also be easier for them since they are 
less prone to move for job-related reasons. With respect to lone mothers employed in service-sector occupations, it is possible that certain characteristics of their jobs make it easier for them to meet new partners. Possibly, they meet more people on a daily basis or have a larger number of younger colleagues than do people employed in other types of occupations.

Nonetheless, it is still interesting that non-employment and service sector employment have positive effects on transitions into new partnerships for lone mothers, but not for childless women. If the reason for these effects among lone mothers is indeed severe economic difficulties, and not unobserved differences in preferences or opportunities to meet new partners, then this would indicate an important loss of personal autonomy.

\section{Acknowledgements}

I would like to thank Dorothea Rieck and David Alich for very helpful advice on working with the Russian GGS and EES data. I am grateful to Jan Hoem as well as all the members of the team on Institutional and Political Approaches to Family and Fertility Dynamics for valuable comments and advice.

\section{References}

Alexeev, Michael V. and Clifford G. Gaddy 1993. Income Distribution in the U.S.S.R. in the 1980s. Review of Income and Wealth 39, no. 1: 23-36.

Becker, Gary S. 1993. A Treatise on the Family. Cambridge, Mass.

Blossfeld, Hans-Peter and Johannes Huinink. 1991. Human Capital Investments or Norms of Role Transitions? How Women's Schooling and Career Affect the Process of Family Formation. American Journal of Sociology 97, no. 1: 143-68.

Bracher, Michael and Gigi Santow. 1998. Economic Independence and Union Formation in Sweden. Population Studies 52, no. 3: 275-94.

Brainerd, Elizabeth. 2000. Women in Transition: Changes in Gender Wage Differentials in Eastern Europe and the Former Soviet Union. Industrial and Labor Relations Review 54, no. 1: 138-62.

Brewer, Mike, Alissa Goodman, Jonathan Shaw, and Andrew Shepard. 2005. Poverty and Inequality in Britain: 2005. The Institute for Fiscal Studies. Commentary No. 99. 
Brüderl, Josef and Andreas Diekmann. 1994. Bildung, Geburtskohorte und Heiratsalter. Eine vergleichende Untersuchung des Heiratsverhaltens in Westdeutschland, Ostdeutschland und den Vereinigten Staaten. Zeitschrift für Soziologie 23, no. 1: 56-73.

Cherry, Robert. 2007. Assessing Welfare Reform Data: A Comment on Christopher. Feminist Economics 13, no. 2: 185-95.

Christopher, Karen. 2004. Welfare as We [Don’t] Know It: A Review and Feminist Critique of Welfare Reform Research in the United States. Feminist Economics 10, no. 2: 143-71.

Christopher, Karen. 2007. Reassessing Welfare Reform Data: A Response to Cherry. Feminist Economics 13, no. 2: 197-202.

Corcoran, Mary, Sandra K. Danziger, Ariel Kalil, and Kristin S. Seefeldt. 2000. How Welfare Reform is Affecting Women's Work. Annual Review of Sociology 26: 241-69.

Council of Europe. 2005. Recent Demographic Developments in Europe. Strasbourg.

Dilnot, Andrew, and Julian McCrae. 2000. The Family Credit System and the Working Family Tax Credit in the United Kingsom. OECD Economic Studies 31, no. 2: 69-84.

Duvander, Ann-Zofie E. 1999. The Transition from Cohabitation to Marriage. A Longitudinal Study of the Propensity to Marry in Sweden in the Early 1990s. Journal of Family Issues 20, no. 5: 698-717.

Ezawa, Aya and Chisa Fujiwara. 2005. Lone Mothers and Welfare-to-Work Policies in Japan and the United States: Towards an Alternative Perspective. Journal of Sociology and Social Welfare 32, no. 4: 4163.

Federal State Statistics Service. 2005. Russia in Figures. Moscow

Francesconi, Marco and Wilbert van der Klaauw. 2004. The Consequences of 'In-Work' Benefit Reform in Britain: New Evidence from Panel Data. IZA Discussion Paper, no. 1248.

Generations and Gender Contextual Data Base. 2008. http://www.demogr.mpg.de/

Gerber, Theodore P., and Michael Hout. 1998. More Shock than Therapy: Market Transition, Employment, and Income in Russia, 1991-1995. American Journal of Sociology 104, no. 1: 1-50.

Goldstein, Joshua R. and Catherine T. Kenney. 2001. Marriage Delayed or Marriage Forgone? New Cohort Forecasts of First Marriage for U.S. Women. American Sociological Review 66, no. 4: 506-519.

Gustafsson, Björn, Li Shi, Ludmila Nivorozhkina, Katarina Katz. 2001. Rubles and Yuan: Wage Functions for Urban Russia and China at the End of the 1980s. Economic Development and Cultural Change 50, no. 1: 1-17.

Hansberry, Rita. 2004. An Analysis of Gender Wage Differentials in Russia from 1996-2002. William Davidson Institute Working Paper, no. 720.

HM Revenue \& Customs. 2008. What are tax credits? http://www.taxcredits.inlandrevenue.gov.uk/qualify/WhatAreTaxCredits.aspx

Hoem, Jan M. 1986. The Impact of Education on Modern Family-Union Initiation. European Journal of Population 2: 113-33.

— 2000. Systematic Patterns of Zero Exposures in Event-History Analysis. Sociological Methodology 30: 237-59.

Hoem, Jan M., Aiva Jasilioniene, Dora Kostova, and Cornelia Muresan. 2007. Traces of the second demographic transition in selected countries in Central and Eastern Europe: union formation as a 
demographic manifestation. MPIDR Working Paper, no. 2007-026 (revised January 2008).

Inland Revenue. 2002. Child Tax Credit and Working Tax Credit. An Introduction. PS 721A5. Reprint: 2002

Jasilioniene, Aiva. 2007. Premarital conception and divorce risk in Russia in light of the GGS data. MPIDR Working Paper, no. WP 2007-025.

Kanji, Shireen. 2004. The Route Matters: Poverty and Inequality Among Lone-Mother Households in Russia. Feminist Economics 10, no. 2: 207-25.

Konietzka, Dirk and Kreyenfeld, Michaela. 2005. Nichteheliche Mutterschaft und soziale Ungleichheit im familialistischen Wohlfahrtsstaat. Zur sozioökonomischen Differenzierung der Familienformen in Ost- und Westdeutschland. Kölner Zeitschrift für Soziologie und Sozialpsychologie 57, no. 1: 3261.

Köppen, Katja (2008) Chapter 2: Theoretical Framework. in: Marriage and Cohabitation in West Germany and France. (Draft of Dissertation).

Liefbroer, Aart C., and Martine Corijn. 1999. Who, What, Where, and When? Specifying the Impact of Educational Attainment and Labour Force Participation on Family Formation. European Journal of Population: 45-75.

van der Lippe, Tanja and Éva Fodor. 1998. Changes in Gender Inequality in Six Eastern European Countries. Acta Sociologica: 131-149.

Lokshin, Michael. 2004. Household Childcare Choices and Women's Work Behavior in Russia. The Journal of Human Resources 39, no. 4: 1094-115.

Lokshin, Michael, Kathleen Mullan Harris, and Barry M. Popkin. 2000. Single Mothers in Russia: Household Strategies for Coping with Poverty. World Development 28, no. 12: 2183-98.

Luxán, Marta, Pau Miret and Rocío Treviño. 1999. Is the Male-Provider Model Still in Place? Partnership Formation in Contemporary Spain. South European Society and Politics 4, no. 2: 171-94.

McKinney, Judith Record. 2004. Lone Mothers in Russia: Soviet and Post-Soviet Policy. Feminist Economics 10, no. 2: 37-60.

Moskoff, William. 1983. Divorce in the USSR. Journal of Marriage and the Family 45, no. 2: 419-25.

Newell, Andrew, and Barry Reilly. 1996. The Gender Wage Gap in Russia: Some Empirical Evidence. Labour Economics 3: 337-56.

Newell, Andrew, and Barry Reilly. 1999. Rates of Return to Educational Qualifications in the Transition Economies. Education Economics 7, no. 1: 67-84.

Oberemko, O. A. 2006. Household Spending on Preschool Education and Upbringing. Russian Education and Society 48, no. 12: 38-63.

Ogloblin, Constantin G. 1999. The Gender Earnings Differential in the Russian Transition Economy. Industrial and Labor Relations Review 52, no. 4: 602-27.

Okun, Barbara S. 2001. The Effects of Ethnicity and Educational Attainment on Jewish Marriage Patterns: Changes in Israel, 1957-1995. Population Studies 55, no.1: 49-64.

Ono, Hiromi. 2003. Women's Economic Standing, Marriage Timing, and Cross-National Contexts of Gender. Journal of Marriage and Family 65: 275-86.

Pascall, Gillian, and Nick Manning. 2000. Gender and Social Policy: Comparing Welfare States in Central and Eastern Europe and the former Soviet Union. Journal of European Social Policy 10, no. 3: 
240-266.

Rake, Katherine. 2001. Gender and New Labour's Social Policies. Journal of Social Policy 30, no. 2: 20931.

Rieck, Dorothea. 2006. Transition to Second Birth - The Case of Russia. MPIDR Working Paper WP 2006036.

Rowlingson, Karen and Jane Millar. 2002. Lone Parents, Poverty and Work: Policy Approaches and Lessons from Abroad. Benefits 35-10, no. 3: 207-13.

Santow, Gigi and Michael Bracher. 1994. Change and Continuity in the Formation of First Marital Unions in Australia. Population Studies 48, no. 3: 475-96.

Sweeney, Megan M. 2002. Two Decades of Family Change: The Shifting Economic Foundations of Marriage. American Sociological Review 67, no.1: 132-47.

Teplova, Tatyana. 2007. Welfare State Transformation, Childcare, and Women's Work in Russia. Social Politics: International Studies in Gender, State, and Society. Special Issue: Gender and State in Post-Communist Societies 14, no. 3: 284-322.

Trapido, Dennis. 2007. Gendered Transition: Post-Soviet Trends in Gender Wage Inequality among Young Full-Time Workers. European Sociological Review 23, no. 2: 223-37.

United Nations Statistics Division. 2007. Economically Active Population by sex, 13 Age Groups (ILO Estimates/ Projections) [code 4230]. http://unstats.un.org/unsd/default.htm

Xie, Yu, James M. Raymo, Kimberly Goyette, and Arland Thornton. 2003. Economic Potential and Entry into Marriage and Cohabitation. Demography 40, no. 2: 351-67. 